\title{
ANALISIS FAKTOR YANG BERHUBUNGAN DENGAN DENGETAHUAN KADER TENTANG DETEKSI DINI RISIKO TINGGI KEHAMILAN DI WILAYAH KERJA PUSKESMAS CIKULUR TAHUN 2018
}

\section{FACTOR ANALYSIS RELATED TO CADER KNOWLEDGE ABOAT EARLY DETECTION OF HIGH RISK PREGNANCY IN THE WORKING AREA OF CIKULUR HEALTH CENTER IN 2018}

\author{
Suhartini, Ahmad \\ Poltekkes Kemenkes Banten \\ Korespondensi: suhartini@poltekkesbanten.ac.id
}

\section{ABSTRACT}

SDGs, target bring down number dead mother to below 70 per 100,000 KH and bring down number dead neonatal to 12 per $1000 \mathrm{KH}$. . Data from the Lebak District Health Office revealed that the number of maternal deaths in 2015 was 43 people and in 201638 people and 2017 up to October numbered 30 people. Cikulur Health Center data shows an increase in the number of maternal deaths since 2015 with no 2016 deaths of 1 (one) death and in 2017 there were 2 (two) deaths of mothers. From the data it is not yet known the cadre's knowledge about early detection of high risk of pregnancy. This study aims to determine the knowledge of cadres about early detection of high-risk pregnancies in the cikulur sub-district health center in Lebak district

The methodology of this research is the design of the "croos sectional" study population, which is health cadres in the cikulur sub-district and the number of samples is 120 health cadres in the work area of the Cikulur health center. The sampling technique was calculated using the sample calculation formula, obtained a sample of 120 people in 34 posyandu. Each posyandu is recorded by 3-4 cadres. Research held sine month my to with November 2018

Research shows that found (28,3\% ) cadres who have less knowledge about early detection of high risk of pragnancy, (75\%) Cadres last education TP SLTP (70,8\%) Cadres have never attendeed training related to detection of High Risk of Pregnancy there are still $(15,8 \%)$ cadres who have become cadres $\leq 1$ year.

Most $(84,2 \%)$ cadres stated that they did not have a guideline for early detection of high risk pregnancy. The result of the analysis continued to be known that, the knowledge of cadresswasless about early detection of high risk of pragnancy proportion more high on group education cadre $\leq$ Junior high school $(31,9 \%)$, have never attended cadre training $(21,2)$. Group < 1 year became cadre $(42,1)$, group availability of guidelines $(42,1 \%$ and cadres obtain informal information sources $(33,3 \%)$, but the results of further analysis of several variabels stated do not show the relationship between education, training, long time as cadress, avaibility of guidelines and sources of information with knowlodge about early detection of high risk pregmnancies $P$ value $>$ from 0.05 .

Considering that there are still cadres who are less knowledgeable and have not been trained, and do not have guidance to detect high risk pregnancies, it is recommended that puskesmas improve training, provide guidelines, and create brochures, leaflets and pocket 
books for early detection of high risk pregnancies, develop models KIA surveillance coordinates with the health department and lecturers in the next research and community service activities

\section{Keywords; Detection, RISTI, Pregnant Women}

\section{ABSTRAK}

SDGs, mentargetkan menurunkan Angka Kematian Ibu hingga dibawah 70 per 100.000 KH dan menurunkan Angka Kematian Neonatal menjadi 12 per 1000 KH..Data dari Dinas kesehatan Kabupaten Lebak diketahui bahwa jumlah kematian ibu tahun 2015 berjumlah 43 orang dan tahun 201638 orang dan tahun 2017 s/d Okober berjumlah 30 orang. Data Puskesmas Cikulur menunjukan terjadi peningkatan jumlah kematian ibu sejak tahun 2015 tidak ada kematian 2016 ada 1 (satu) kematian dan pada tahun 2017 dilaporkan sebanyak 2 (dua) kasus kematian Ibu. Dari data belum diketahui pengetahuan kader tentang deteksi dini risiko tinggi kehamilan. Penelitian ini bertujuan untuk mengetahui pegetahuan kader tentang deteksi dini risiko tinggi kehamilan di Puskesmas kecamatan cikulur kabupaten lebak

Metodelogi penelitian ini menggnakan desain "croos sectional" populasi penelitian adalah Kader kesehatan di kecamatan cikulur dan jumlah sampel sebanyak 120 orang kader kesehatan di wilayah kerja puskesmas Cikulur. Tehnik pengambilan sampel dihitung dengan menggunakan rumus perhitungan sampel, didapatkan sampel 120 orang di 34 posyandu. Masing-masing posyandu didata 3-4 orang kader. Penelitian dilaksanakan sejak bulan Mei sampai dengan November 2018

Hasil Penelitian menunjukkan bahwa Masih ditemukan $(28,3 \%)$ Kader yang memiliki pengetahuan kurang tentang deteksi dini resiko tinggi kehamilan, $(75,8 \%)$ Kader pendidikan terakhir $\leq$ SLTP., $(70,8 \%)$ Kader belum pernah mengikuti pelatihan terkait Deteksi Risiko Tinggi kehamilan., Masih terdapat $(15,8 \%)$ Kader yang lama menjadi kader nya $\leq 1$ Tahun. Sebagian besar $(84,2 \%)$ Kader menyatakan tidak memiliki pedoman deteksi dini resiko tinggi kehamilan, Hasil analis lanjut diketahui bahwa, Pengetahuan kader kurang tentang deteksi dini resiko tinggi kehamilan proporsinya lebih tinggi pada kelompok pendidikan kader $\leq$ SLTP $(31,9 \%)$, belum pernah mengikuti pelatihan kader $(21,2 \%)$. kelompok <1 tahun menjadi kader (42,1\%), kelompok tersedianya pedoman (42,1 \%), dan Kader memperoleh sumber informasi informal $(33,3 \%)$,namun hasil analisis lanjut dari beberapa variabel dinyatakan tidak menunjukkan hubungan yang antara pendidikan, pelatihan, lama menjadi kader, ketersediaan pedoman dan sumber informasi dengan pengetahuan tentang deteksi dini risiko tinggi kehamilan P.value > dari 0.05.

Mengingat masih ditemukan kader yang berpengetahuan kurang dan belum terlatih, serta tidak memiliki petoman untu melakukan deteksi risiko tinggi kehamilan, maka disarankan kepada puskesmas untuk meningkatkan pelatihan, menyediakan pedoman, serta membuat brosur,leaflet, dan buku saku deteksi dini risiko tinggi kehamilan, mengembangkan model surveilans KIA berkoordinasi dengan dinas kesehatan maupun dosen pada kegiatan penelitian dan pengabdian kepada masyarakat berikutnya

\section{Kata Kunci; Deteksi , RISTI , Ibu Hamil}




\section{PENDAHULUAN}

Di dunia setiap menit seorang perempuan meninggal karena komplikasi yang terkait dengan persalinan. Dengan kata lain, 1400 perempuan meninggal setiap hari atau lebih dari 500.000 perempuan meninggal setiap tahun karena persalinan. Di Indonesia 2 orang Ibu meninggal setiap jam karena kehamilan, persalinan dan nifas (WHO, 2008).

Menurut Organisasi Kesehatan Dunia atau World Health Organization (WHO) menjelaskan bahwa Angka Kematian Ibu (AKI) 2011 di Indonesia menduduki peringkat ke-6 dibandingkan dengan negaranegara di ASEAN yaitu 125/100.000 kelahiran hidup (WHO,2011).

Menurut survei Demografi Kesehatan Indonesia (SDKI) tahun 2012, Angka Kematian Ibu (AKI) di Indonesia mencapai 359 per 100.000 kelahiran hidup dan Angka Kematian Bayi (AKB) mencapai 32 per 1000 kelahiran hidup. Dalam rangka mencapai tujuan ke 3 SDGs yaitu; menjamin kehidupan yang sehat dan mendorong kesejahteraan bagi semua orang di segala usia pada tahun 2030 SDGs, mentargetkan menurunkan Angka Kematian Ibu hingga dibawah 70 per $100.000 \mathrm{KH}$ dan menurunkan Angka Kematian Neonatal menjadi 12 per $1000 \mathrm{KH}$
Penyebab masalah tingginya AKI dan $\mathrm{AKB}$ di Indonesia ada dua yaitu penyebab langsung dan tidak langsung. Beberapa penyebab tidak langsung terbagi dalam tiga T yakni terlambat mengambil keputusan, terlambat ke tempat rujukan serta terlambat memberi pertolongan di tempat rujukan. Untuk penyebab langsung kematian ibu di Indonesia, seperti halnya di negara lain adalah perdarahan, infeksi dan eklampsia.

Data yang didapatkan dari Profil Dinas Kesehatan Provinsi Banten pada tahun 2013, jumlah Angka Kematian Ibu (AKB) berkisar 116 orang yang disebabkan oleh perdarahan 55 orang $(47,41 \%)$, hipertensi dalam kehamilan 25 orang $(21,55 \%)$, infeksi 2 orang (1,72\%), abortus 3 orang (2,58\%), dan penyebab lainnya 31 orang $(26,72 \%)$, (Profil Dinas Kesehatan Provinsi Banten 2013).

Data dari Dinas kesehatan Kabupaten Lebak diketahui bahwa jumlah kematian ibu tahun 2015 berjumlah 43 orang dan tahun 201638 orang dan tahun 2017 s/d Okober berjumlah 30 orang. Penyebab kematian ibu diantaranya adalah karena perdarahan, eklampsi/preeklampsia dll. Apabila dilihat dari status obstetri lebih banyak pada kehamilan ke2-3 yang seharusnya tidak termasuk kelompok risiko tinggi dan apabila dilihat dari tempat meninggal hampir 50\% kasus meninggal di RS, hal ini menunjukkan bahwa kasus-kasus yang dirujuk ke RS 
sudah dalam kondisi lanjut. Data Puskesmas Cikulur menunjukan terjadi peningkatan jumlah kematian ibu sejak tahun 2015 tidak ada kematian 2016 ada 1 (satu) kematian dan pada tahun 2017 dilaporkan sebanyak 2 (dua) kasus kematian.

Menyikapi data-data yang ada, maka kader kesehatan memiliki peran yang besar dalam hal deteksi dini risiko tinggi kehamilan dan persalinan, Sejauhmana pengetahuan kader tentang deteksi dini faktor risiko tinggi kehamilan di wilayah kerja puskesmas Cikulur pada tahun 2018 ini belum diketahui. Tujuan penelitian ini untuk mengetahui faktor -faktor yang berhubungan dengan pengetahuan kader tentang deteksi dini risiko tinggi kehamilan di wilayah kerja puskesmas Cikulur tahun 2018

\section{METODE}

Desain penelitian ini adalah Desain Cross sectional merupakan rancangan penelitian dengan melakukan pengukuran/ pengamatan pada saat bersamaan (sekali waktu) antara faktor risiko/paparan dengan penyakit.

Populasi penelitian ini adalah seluruh kader (170 orang) di Kecamatan Cikulur yang tersebar di 34 Posyandu.Sampel Penelitian total setelah dilakukan perhitungan diperoleh sebanyak 120 orang Kader

\section{HASIL DAN PEMBAHASAN}

1. Pengetahuan tentang deteksi dini risiko tinggi Kehamilan

Penelitian ini menunjukkan bahwa masih ditemukan kader dengan pengetahuan rendah sebesar $(28,3 \%)$, penelitian ini sejalan dengan hasil penelitian yang dilakukan oleh Akhmad Fatoni dkk tentang peran kader dalam deteksi dini ibu hamil dan neonatus di kota Mataram ditemukan sebanyak 24 orang (50\%), responden dengan tingkat pengetahuan kurang, pengetahuan cukup sebanyak 22 orang $(45,8 \%)$, dan responden dengan tingkat pengetahuan baik sebanyak (4,2\%)..Dari hasil penelitian ini menunjukkan bahwa perlu satu intervensi bersama lintas program dan sektoral terkait untuk meningkatkan pengetahuan dan pemahaman Kader tentang deteksi dini risiko tinggi ibu hamil. Hal ini penting dilakukkan, mengingat kader adalah perpanjangan tangan petugas kesehatan dan merupakan orang yg terdekat dengan ibu hamil di Desa. Apabila Kader berpengetahuan baik tentang deteksi dini risiko tinggi ibu hamil, maka diharapkan faktor risiko tinggi kehamilan dapat diketahui lebih dini untuk dilalukan penanganan yang 
cepat dan tepat, dan hal ini sangat berpengaruh terhadap penurunan angka kematian ibu hamil di desa

\section{Pendidikan Kader}

Hasil penelitian ini mendapatkan bahwa Sebagian besar $\quad(75,8 \%)$ Kader pendidikan terakhir $\leq$ SLTP. Hasil analisis lanjut menunjukkan bahwa kader yang berpengetahuan kurang tentang deteksi dini resiko tinggi kehamilan proporsinya lebih tinggi pada kelompok kader dengan pendidikan $\leq$ SLTP $(31,9 \%)$, dibandingkan dengan kelompok kader dengan pendidikan > SLTP $(17,2$ $\%)$. Pendidikan sangat berpengaruh terhadap pengetahuan dan berpengaruh pula terhadap sikap dan perilaku seseorang. Pendidikan kesehatan yang diberikan merupakan upaya persuasi atau pembelajaran agar masyarakat mau melakukan praktik untuk memelihara dan meningkatkan kesehatannya dengan didasarkan kepada pengetahuan dan kesadarannya melalui proses pembelajaran sehingga perilaku tersebut diharapkan dapat berlangsung lama. Sangat di sayangkan apabila orang yang menyampaikan pembelajaran dalam hal ini adalah Kader kesehatan di desa memiliki latar belakang pendidikan yang rendah, hal ini akan berdampak kepada rendahnya pula pengetahuan. Kegitan pelatihan yang konsisten dan terarah sangat diperlukan untuk mengimbangi pendidikan yang rendah. Menurut Noto Atmojo (2010) bahwa faktor yang mempengaruhi pengetahuan kader salah satunya adalah pendidikan. Hasil penelitian ini juga sejalan dengan hasil penelitian yang dilakukan oleh Akhmad Fatoni dkk bahwa masih ditemukan kader berpendidikan rendah sebesar $45,4 \%$. Pendidikan sangat berpengaruh terhadap pemahaman dan pengetahuan yang pada akhirnya berpengaruh kepada penyampaian informasi secara baik dan benar khususnya pemahaman tentang deteksi dini risiko tinggi ibu hamil di wilayahnya.

\section{Pelatihan Kader}

Dari hasil penelitian sebanyak 85 orang dari 120 Kader $\quad(70,8 \%)$ Kader menyatakan belum pernah mengikuti pelatihan tentang Deteksi Dini Risiko tinggi ibu hamil. Hasil analisis lanjut menunjukkan bahwa kader yang berpengetahuan kurang tentang deteksi dini resiko tinggi kehamilan proporsinya lebih tinggi pada kader yang pernah mengikuti pelatihan kader $\geq 1$ kali (45,7\%), dibandingkan kelompok yang belum pernah mengikuti pelatihan kader 
$(21,2 \%)$. Hal ini menunjukkan bahwa dengan pelatihan $\geq 1$ kali masih belum mencukupi untuk meningkatkan pengetahuan kader tentang deteksi risiko tinggi kehamilan

Hasil ini sejalan dengan penelitian Triana Widiastuti $\mathrm{dkk}$ tentang manajemen deteksi dini ibu hamil risiko tinggi pada pelayanan antenatal di tingkat puskesmas kabupaten jepara “ menunjukkan tidak ada pelatihan khusus untuk penjaringan deteksi dini risiko tinggi pada ibu hamil akan tetapi pelatihan yang ada dalam bentuk bimbingan teknis". Hal ini menunjukkan bahwa selain pelatihan perlu bimbingan specifik terkait deteksi dini risiko tinggi kehamilan. Deteksi dini kehamilan sendiri adalah kegiatan yang dilakukan untuk menemukan ibu hamil yang mempunyai faktor risiko dan komplikasi kebidanan (Depkes RI, 2010). Apabila Kader tidak diberikan bimbingan dalam menemukan ibu hamil risti, maka screening terhadap kasus-kasus risiko tinggi di desa pun kurang berjalan baik.

\section{Lama menjadi Kader}

Hasil penelitian menunjukkan bahwa masih terdapat $(15,8 \%)$ kader yang lama menjadi kader nya $\leq 1$ Tahun. Hasil analisis lanjut menunjukkan bahwa kader yang berpengetahuan kurang tentang deteksi dini resiko tinggi kehamilan proporsinya lebih tinggi pada kelompok yang lama menjadi kadernya $\leq$ 1 tahun (42,1\%), dibandingkan dengan kelompok yang lama menjadi kadernya lebih dari > 1 tahun $(25,7 \%)$. Hasil analisis lanjut didapatkan alpha 0,24 artinya tiak ada hubungan antara lama menjadi kader dengan pengetahuan tentang deteksi dini risiko tinggi kehamilan. Hasil penelitian ini sejalan dengan penelitian Colti Sulistiarini menggambarkan bahwa kader yang memiliki masa kerja lama dan memiliki peran kader dalam penggunaan buku KIA untuk deteksi dini sebesar 47,6\%. Sedangkan kader yang memiliki masa kerja baru sebesar 45,9\%. Disimpulkan tidak ada hubungan masa kerja dengan peran kader dalam menggunakan buku KIA.

Seharusnya lama menjadi Kader ini menjadi penting karena Kader yang lama akan lebih banyak belajar dari pengalaman yang sudah dilewatinya, sedangkan kader yang baru apabila tidak diimbangi dengan pelatihan dan bimbingan terkait deteksi dini risiko tinggi kehamilan, maka pengetahuan tentang deteksi dini risiko tinggi ibu hamil pun tidak optimal, sehingga tidak dapat mengenal dengan baik tentang risiko tinggi kehamilan. Seharusnya semakin 
lama seseorang mengabdi, maka semakin banyak pengalaman dan keterampilan seseorang dalam melakukan pekerjaan.

\section{Ketersediaan Pedoman}

Hasil penelitian menunjukkan sebagian besar $(84,2 \%) \quad$ Kader menyatakan tidak memiliki pedoman deteksi dini resiko tinggi kehamilan. Hasil analisis lanjut menunjukkan bahwa kader yang berpengetahuan kurang tentang deteksi dini resiko tinggi kehamilan proporsinya lebih tinggi pada kelompok yang tersedianya pedoman $(42,1 \%)$, dibandingkan dengan kelompok yang tidak tersedianya pedoman $(25,7 \%)$. Bila pedoman tentang deteksi dini ini tidak tersedia, maka peranan kader dalam penapisan ibu hamil risiko tinggi menjadi kurang optimal karena tidak memiliki pegangan yang mendasari tindakannya. Dari hasil uji statistik Chi-square menggunakan Continuity correction dengan nilai $\mathrm{P}=0,240 \geq \alpha(0,05)$ maka $\mathrm{H}_{0}$ diterima, $\mathrm{H}_{\mathrm{a}}$ ditolak. Dari analisa di atas maka dapat disimpulkan bahwa tidak ada hubungan antara ketersediaan pedoman dengan pengetahuan kader tentang deteksi dini resiko tinggi kehamilan.

\section{SIMPULAN}

1. Masih ditemukan $(28,3 \%)$ Kader yang memiliki pengetahuan kurang tentang deteksi dini resiko tinggi kehamilan.

2. Sebagian besar $(75,8 \%)$ Kader pendidikan terakhir $\leq$ SLTP.

3. Sebagian besar $(70,8 \%)$ Kader belum pernah mengikuti pelatihan terkait Deteksi Risiko Tinggi kehamilan.

4. Masih terdapat $(15,8 \%)$ Kader yang lama menjadi kader nya $\leq 1$ Tahun.

5. Sebagian besar $(84,2 \%)$ Kader menyatakan tidak memiliki pedoman deteksi dini resiko tinggi kehamilan

6. Hasil analis diketahui bahwa, Pengetahuan kader kurang tentang deteksi dini resiko tinggi kehamilan proporsinya lebih tinggi pada kelompok pendidikan kader $\leq$ SLTP $(31,9 \%)$, belum pernah mengikuti pelatihan kader $(21,2 \%)$. kelompok <1 tahun menjadi kader (42,1\%), kelompok tersedianya pedoman $(42,1 \%)$, dan lebih tinggi pada kelompok yang menerima sumber informasi informal $(33,3 \%)$, 


\section{DAFTAR RUJUKAN}

Akhmad Fatoni at al, Jurnal kesehatan prima, Vol.6 no 2 tahun 2012. Peran kader dalam deteksi risiko tinggi ibu hamil dan Neonatus, Poltekkes Kemenkes Mataram 2012

http://Journal unes ac.id /nju/indeks/php/kesmas colti sulistiarini dkk, Peran Kader dalam penggunaan buku Kesehatan ibu dan anak. Universitas negeri semarang, th 2013

http://ejournal.Sl.undip.ac.id/indeks/php/ JKM. Tiara Asfiya. Sidik.. Hubungan media informasi dengan tingkat pengetahuan kesehatan reproduksi pada santri pondok pesantren darut taqwa Bulusan Semarang

Depkes RI 2009, Buku Pegangan Kader , Buku Paket Pelatihan Kader Kesehatan dan Tokoh masyarakat dalam pengembangan Desa Siaga, Jakarta 2009

Depkes RI 2007, Pedoman surveilans KIA, Peningkatan Kapasitas Agen Perubahan dalam kesehatan Ibu dan anak Direktorat Jendra Bina Kesmas, Jakarta 2007

Depkes RI 2009, Pedoman Pemantauan Wilayah Setempat Kesehatan Ibu dan Anak, Jakarta; Depkes RI

Fitria Hayu pahlupi at al., Tingkat pengetahuan Kader Kesehatan tentang Tanda dan Bahaya Kehamilan di Desa Bolon Kecamatan Colomadu ,Jurnal KesMas Daska , Januari 2013

Ircham Mahfuoedz, Eko Suryani, Pendidikan Kesehatan bagian dari Promosi Kesehatan, Tramaya Yogyakarta, 2006

NotoAtmojo,Soekidjo (2007), Promosi kesehatan teori dan aplikasinya, PT Rineka Cipta,Jakarta
NotoAtmojo,Soekidjo (2010), Metodologi penelitian kesehatan; Rineka Cipta, Jakarta

Nani Khomsah, Skripsi. Faktor-faktor yang berhubungan dengan peran serta kader posyandu dalam deteksi faktor risiko ibu hamil di wilayah kerja puskesmas Buayan Kebumen Jawa Tengah 2012

Reni Dwi Setyaningsih, Jurnal Pengabdian Masyarakat Vol 22 No 3 Jul-Des 2016. ISSN 0852-2715 / e ISSN 2502-7220. Upaya peningkatan pengetahuan ibu hamil dan kader Posyandu Balita tentang pengenalan tanda dan bahaya kehamilan di kabupaten Banyumas tahun 2016

Siti Zoor Zaenab. Modul 1 program kebijakan kesehatan Ibu dan Anak, Surveilans Respon dalam program KIA

Triana Widiastuti dkk, Manajemen deteksi dini ibu hamil risiko tinggi pada pelayanan antenatal di tingkat puskesmas kabupaten jepara, Jumal Manajemen Kesehatan di Indonesia vol.02 no 03 tahun 2014

Yulifah Rita,et,al (2009), Asuhan kebidanan komunitas, Salemba Medika Jakarta

Winjosastro,Hanifa (2008), Ilmu Kebidanan. PT Yayasan Bina Pustaka 